\title{
Thrixspermum changlangensis sp. nov. [Orchidaceae: Epidendroideae: Vandeae: Aeridinae] from Arunachal Pradesh in Northeast India
}

\author{
KhyanjeetGogoi \\ TOSEHIM, Regional Orchid Germplasm Conservation \& Propagation Centre (Assam Circle) \\ DaisaBordoloi Nagar, Talap, Tinsukia- 786 156, Assam, India \\ E-mail:khyanjeetgogoi@gmail.com
}

[Received 20.05.2019; Revised 20.06.2019; Accepcepted 23.06.2019; Published 30.06.2019]

\begin{abstract}
A new species of orchid, viz. Thrixspermum changlangensis from tropical evergreen forest in Changlang District of Arunachal Pradesh, India, is described. It is allied to Thrixspermum calceolus (Lindl.) Rchb.f. but quite distinct from this species in having broadly triangular lateral lobes of lip with short lacinate tips and shorter, broadly triangular, obtuse midlobe of lip with glabrous callii on the disc.
\end{abstract}

Key words: Thrixspermum changlangensis, New species, Arunachal Pradesh, India

\section{INTRODUCTION}

The genus Thrixspermum Loureiro(Orchidaceae) comprises of around 161 species (Chase et al. 2015) distributed widely from the Himalayas to Philippines and tropical Islands of S.W. Pacific (Govaertset al. 2016). So far, the genus is represented by 16 species in India (Misra 2007, Maina et al. 1998, Mao et al. 2011, Gogoi 2011, Gogoi \&Yonzone 2015, Vikas Kumar et al. 2017, Gogoi 2018) of which 9 species are recorded from Northeast India including 3 species from Arunachal Pradesh (Hegde 2017) viz. Thrixspermum centipede Lour., T. musciflorum Rao \& Joseph and T. saruwatarii (Hayata) Schltr.

During a field trip to Myanmar through Changlang district of Arunachal Pradesh on 10 June, 2014, the author collected an unidentified epiphytic orchid in its vegetative condition from Nampongarea of Arunachal Pradesh. The orchid was brought under cultivation at the Regional Orchids Germplasm Conservation and Propagation Centre (Assam Circle), Assam where it flowered during May, 2018 after four years. A critical study based on the available literature (Seidenfaden 1975; Pradhan 1979; Das et al. 1980; Chowdhery 1998; King \& Pantling 1898; Gravendeel 2000; Clayton 2002; Pearce \&Cribb 2002; Lucksom 2007; Chen et al. 2009; Rao 2010; Gogoi et al. 2015; Hooker 1890; Ridley 1907; Seidenfaden 1988; Seidenfaden \& Wood, 1992) and the comparison with the herbarium specimens of Thrixspermum collections deposited in the local Herbaria proved that the present collection is an undescribed species. Hence, it is described here as a new species along with a plate of colour illustrations of plant habit and floral dissected parts.

\section{Thrixspermum changlangensis Gogoi sp. nov.}

Typus: India, Arunachal Pradesh, Changlang district, Nampong, 500m, 00802, 10 May 2018, Khyanjeet Gogoi [Holo 00802 A (ASSAM); Iso 00802 B, (DU); Iso 00802 C, (TOSEHIM) (The Orchid Society of Eastern Himalaya)]. [PLATE I] 

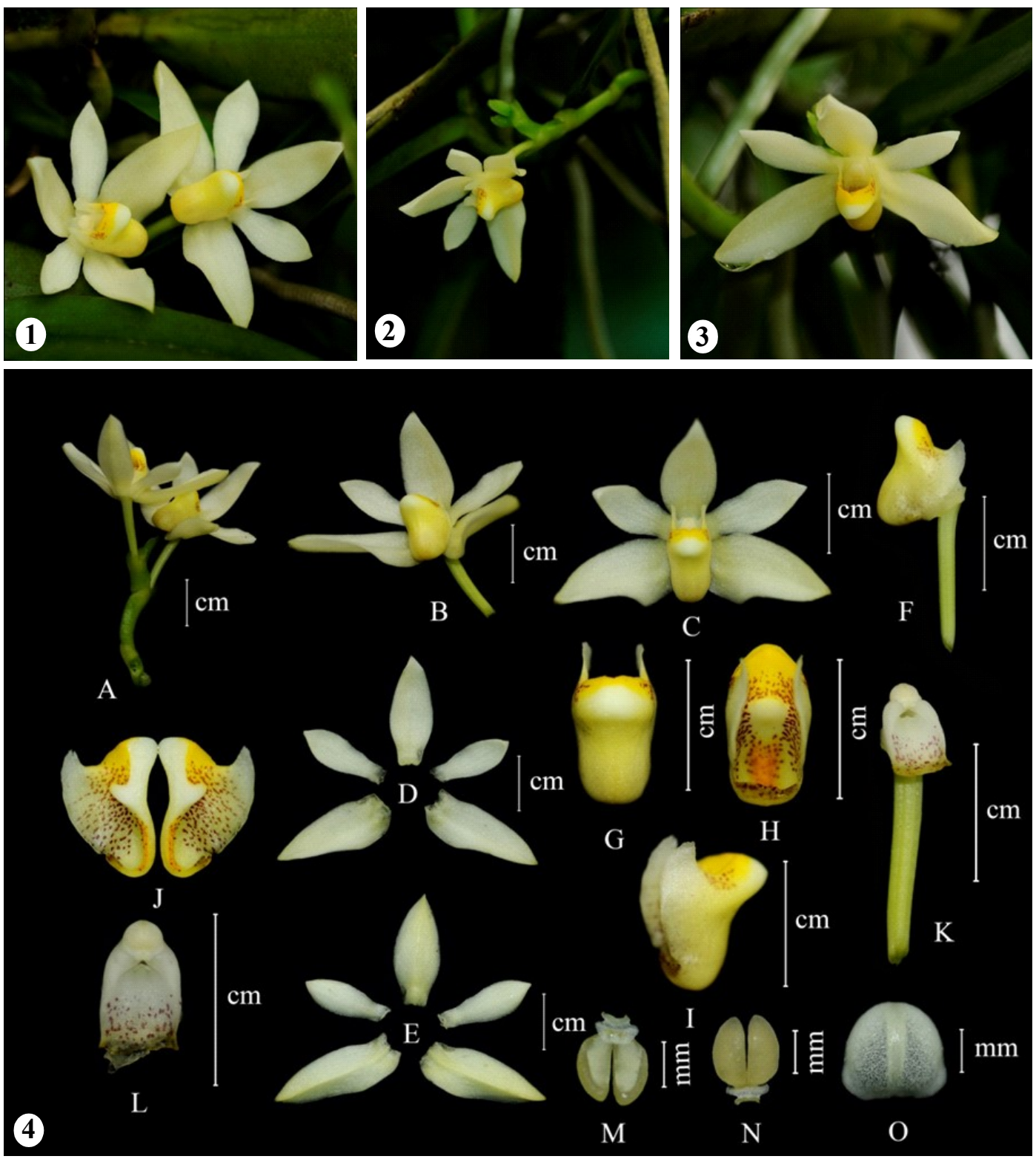

PLATE - I. Thrixspermum changlangensis Gogoi $s p$. nov.: Figures 1 - 3. Different views of flowers; Figure 4. A. Inflorescence; B \& C. Flower; D \& E. Sepals and Petals - ventral and dorsal views; F. Lip with ovary and column; G, H\&I. Lip; J. longitudinal section of lip; K.Pedicel, ovary and column; L. Column; $\mathbf{M} \& \mathbf{N}$. Ventral and dorsal views of pollinarium; $\mathbf{O}$. Anther cap - dorsal view

Plant epiphyte, monopodial; stems stout, $10-30 \mathrm{~cm}$ long or less, slightly flattened, with many leaves; internodes $2-2.5 \mathrm{~cm}$. Leaves fleshy, lanceolate, coriaceous, 5-13 $\times 1.5-2 \mathrm{~cm}$, oblong, narrowed to twisted base and to the unequally bilobed rounded apex; sheaths $1-1.2 \mathrm{~cm}$. Inflorescence 2-2.5 cm long, shorter then leaves, leaf opposite, one or two flowered. Bracts ovate cucullate, $0.5-0.6 \mathrm{~cm}$ long. Flowers last few hours, $4-4.5 \mathrm{~cm}$ across, white, fleshy, fragrant; lip orange yellow with a white tiped side lobes. Sepals $1.8-2.0 \times 0.8-1.0 \mathrm{~cm}$ broad, lanceolate, acute. Petals $1.2-1.5 \times 0.6-0.8 \mathrm{~cm}$, narrower, oblanceolate. Lip $1.2-1.3 \mathrm{~cm}$, 
shoe-shaped, base saccate; side-lobes tringular, erect, $0.4 \mathrm{~cm}$; mid-lobe broadly triangular, tip obtuse, fleshy; callus oblong truncate, retuse at top, all white except orange round callus, and small orange and crimson dots at base of lip. Column $0.6-0.8 \mathrm{~cm}$ with a foot. Pollinia 4 , $0.2 \mathrm{~cm}$ long. Capsules cylindric, $10-12 \mathrm{~cm}$.

Flowering and Fruiting: May- June

Habitat:Epiphytic on trees or branches

General distribution: INDIA (Nampong, Changlang District of Arunachal Pradesh).

Status: Rare; the species was found only in one locality

Etymology: The specific epithet refers to the District 'Changlang', Arunachal Pradesh in Northeast India where from the plant was collected.

Notes : The present new species is more allied to Thrixspermum calceolus (Lindl.) Rchb.f. but quite distinct from this species in having broadly triangular lateral lobes of lip with short lacinatetips ; and shorter, broadly triangular, obtuse midlobe of lip with glabrous callii on the disc. The Differences between T.changlangensis and T.calceolusLour. are shown in the following Table 1.

Table 1. Differences between Thrixspermum calceolus and T. changlangensis

\begin{tabular}{|l|l|l|}
\hline Characters & \multicolumn{1}{|c|}{ Thrixspermum calceolus } & \multicolumn{1}{c|}{ Thrixspermum changlangensis } \\
\hline Plant & $\begin{array}{l}\text { epiphytic, terrestrial or lithophytic, } \\
\text { upto } 360 \mathrm{~cm} \text { long. }\end{array}$ & epiphytic, $10-30 \mathrm{~cm}$ long. \\
\hline Leaves & $6-12 \times 2-3 \mathrm{~cm}$. & $5-13 \times 1.5-2 \mathrm{~cm}$. \\
\hline Sepals & $2.5-4 \mathrm{~cm}$ long & $1.8-2.0 \times 0.8-1.0 \mathrm{~cm}$ broad. \\
\hline Petals & a little smaller than sepals, $2.5-4 \mathrm{~cm}$. & $\begin{array}{l}\text { much smaller than sepals, 1.2-1.5 } \times \\
0.6-0.8 \mathrm{~cm} .\end{array}$ \\
\hline Lip & $\begin{array}{l}\text { pubescent; lateral lobes narrower, } \\
\text { acuminate, curved; midlobe of lip } \\
\text { more than 2 times longer than the } \\
\text { lateral lobes, oblong, terete, pointed. }\end{array}$ & $\begin{array}{l}\text { glabrous; lateral lobes broadly } \\
\text { triangular, shortly lacinate at apex; } \\
\text { midlobe of lip subequal in length with } \\
\text { lateral lobes, not pointed, broadly } \\
\text { triangular, obtuse at tip. }\end{array}$ \\
\hline $\begin{array}{l}\text { Callii on disc } \\
\text { of lip }\end{array}$ & pubescent. & glabrous. \\
\hline
\end{tabular}

\section{Acknowledgements}

The author is grateful to Dr. Hubert Kurzweil, Senior Researcher, National Parks Board, Singapore Botanic Garden and Dr. Abbareddy Nageswara Rao, former Director, Centre for Orchid Gene Conservation of Eastern Himalayan Region (COGCEHR), Manipur, India for providing literature and valuable suggestion during identity of the species.

\section{LITERATURE CITED}

Barua, I.C., 2001. Orchid Flora of Kamrup District. Bishen Singh Mahendra Pal Singh, Dehra Dun.

Chase, M.W., Cameron, K.M., Freudenstein, J.V., Pridgeon, A.M., Salazar, G., Van Den Berg, C. \& Schuiteman, A. (2015) An updated classification of Orchidaceae. Botanical Journal of the Linnean Society 177: 151-174. https://doi.org/10.1111/boj.12234 
Chen X., Z.Liu, G.Zhu, K.Lang, Z.Ji, Y.Luo, X.Jin, P.J.Cribb, J.J.Wood, S.W.Gale, P.Ormerod, J.J.Vermeulen, H.P.Wood, D.Clayton\&A.Bell, 2009. Orchidaceae, in Z.Wu, P.H.Raven\&D.Hong (eds), Flora of China, vol. 25. Science Press, Beijing; Missouri Botanical Garden Press, St. Louis, USA.

Chowdhery, H.J., 1998. Orchid Flora of Arunachal Pradesh. Bishen Singh Mahendra Pal Singh, Dehra Dun, India.

Clayton, D., 2002. The Genus Coelogyne A Synopsis. Natural History Publication (Borneo), Kota Kinabalu, Malaysia.

Das, S.J. \& Jain, S.K. 1980. Orchidaceae. Genus Coelogyne. Fascicles of flora of India 5. Botanical Survey of India, Howrah.

Gogoi, K.; Das, R. \& Yonzone, R. 2015. Orchids of Assam, North East India - An annotated checklist. Intn. J. Pharm. Life Sci. 6(1): 4123 - 4156.

Gogoi, K. 2018. Wild Orchids of Assam - A Pictorial Guide. Assam State Biodiversity Board, Guwahati, Assam.

Govaerts, R., Campacci, M.A., Baptista, D.H., Cribb, P.J., George, A., Kreutz, K. \& Wood, J.J. 2016. World checklist of Orchidaceae. The Board of Trustees of the Royal Botanic Gardens, Kew. Published on the Internet. Available from: http://apps.kew.org/ wcsp/ (accessed 1 September 2018).

Gravendeel, B., 2000. Reorganising the orchid genus Celogyne- a Phylogenetic Classification Based on morphology and molecules. National Herbarium Nederland.

Hegde, S.N. 2017. Orchids of Arunachal Pradesh- Revised Edition, Department of Environment and forest, Government of Arunachal Pradesh.

King, G. \& Pantling, R. 1898. The orchids of the Sikkim Himalayas. Annals of the Royal Botanical Garden Calcutta 8: 1-342.

Lucksom, S.Z., 2007. The Orchids of Sikkim and North East Himalaya: Development Area, Jiwan Thing Marg, Gangtok, East Sikkim, India.

Misra, S., 2007. Orchids of India. Bishen Singh Mahendra Pal Singh, Dehra Dun, India.

Pearce, N.R. \&P.J.Cribb, 2002. Orchids of Bhutan: Flora of Bhutan. Vol. 3, No. 3. Royal Botanical Garden, Edinburg.

Pradhan, U.C., 1979. Indian Orchids Guide to Identificationand Culture. Vol.- II.Thomson Prass, Faridabad, India.

Rao, A.N., 2010. Orchid flora of Arunachal Pradesh - an update in: Bulletin of Arunachal Forest Research 26 (1\&2): 82-110.

Seidenfaden, G.S., 1975. Orchid Genera in Thailand III. Dansk BotaniskArkiv29 (4): 4-49.

Vikas Kumar; Verma, D. \& Rao, A.N. 2017. Thrixspermum indicum (Orchidaceae), a new species from Northeast India. Phytotaxa 292 (1): 79-84. 